\title{
BAY LEAF (SYZYGIUM POLYANTHUM) EXTRACT EFFECT ON IL-10 EXPRESSION IN ORAL ULCER
}

\author{
Arina Shafia *, Rochman Mujayanto ${ }^{* *}$, Anggun Feranisa*** \\ * Program Pendidikan Sarjana Kedokteran Gigi, Fakultas Kedokteran Gigi, Universitas Islam Sultan Agung \\ ** Departemen IImu Penyakit Mulut, Fakultas Kedokteran Gigi, Universitas Islam Sultan Agung \\ *** Departemen Oral Biology, Fakultas Kedokteran Gigi, Universitas Islam Sultan Agung \\ Correspondence : Rohman Mujayanto, Departemen Ilmu Penyakit Mulut Fakultas Kedokteran Gigi, Universitas Islam Sultan Agung, \\ JIn. Raya Kaligawe KM. 4 Semarang 50012 ph. (024)6583584 fax. (024)6594366. \\ Email : rochman.mujayanto@unissula.ac.id
}

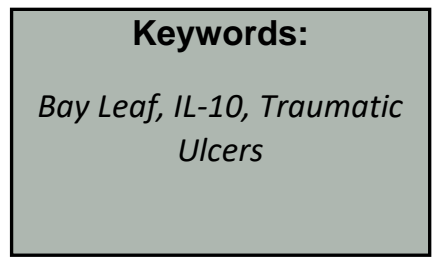

\section{ABSTRACT}

Background: Traumatic ulcers were pathological conditions characterized by loss of epithelial and basal layers resulting from tissue surface excavation caused by trauma. Ulcer healing process consisted of inflammatory, proliferation, and maturation phases. One of the cytokines that play a role in the anti-inflammatory process was IL-10 which worked by balancing the excessive amount of pro-inflammatory cytokines. Bay leaf contained flavonoids which had anti-inflammatory effects. This study's objective is to determine the effect of bay leaf extract gel on IL-10 expression in the healing process of traumatic ulcers.

Method: This study was an analytical study of true experimental laboratories post-test only, consisting of four groups and a sample of 20 male Wistar rats. Mucous ulcers on rat lip were treated with bay leaf extract gel until the 3rd and 5th days. Rat mucosal tissue would be made histological preparations with immunohistochemical staining and calculated IL-10 expression using the Hotspot method. Data obtained then analyzed using Independent T-Test.

Result: Results explained that there was a significant increase in IL-10 expression in the group treated using $10 \%$ bay leaf extract gel than the control group on $3^{\text {rd }}$ and $5^{\text {th }}$ day, which was marked by a significant $p<0.05$.

Conclusion: The conclusion obtained was $10 \%$ bay leaf extract (Syzygium polyanthum) Gel effective in increasing IL-10 expression in the healing of the mucous traumatic ulcer of the mouth of the Wistar rat.

\section{PENDAHULUAN}

Ulkus merupakan keadaan patologis yang ditandai dengan hilangnya lapisan epitel dan lapisan basalis akibat dari ekskavasi permukaan jaringan ${ }^{1}$. Penyebab umum terjadinya ulkus pada membran mukosa mulut adalah trauma, baik itu trauma mekanik, kimia, elektrik, atau suhu. Ulkus ini disebut dengan ulkus traumatikus atau traumatic ulcer ${ }^{2}$.

Proses penyembuhan ulkus terdiri dari fase inflamasi, proliferasi, serta maturasi. Fase-fase ini terjadi saling tumpang tindih (overlapping), dan berlangsung sejak terjadinya luka, sampai tercapainya resolusi luka². Di fase awal inflamasi, terlihat peningkatan sitokin pro-inflamasi yang menyebabkan aktifnya sel imun di daerah infeksi. Sitokin pro-inflamasi dalam jumlah berlebihan dapat merusak dinding vaskular dan mengakibatkan disfungsi organ. Sitokin anti inflamasi seperti IL-10 serta TGF- $\beta$ dilepaskan untuk mengimbangi jumlah sitokin pro-inflamasi yang berlebihan ${ }^{3}$.

IL-10 utamanya berfungsi sebagai penghambat produksi beberapa jenis sitokin (TNF, IL-1, kemokin, serta IL-12), serta menghambat fungsi makrofag serta sel dendritik untuk membantu aktivasi sel-T, sehingga bersifat imunosupresi. IL10 akan menekan ekspresi MHC-II pada 
permukaan makrofag, sehingga terjadi hambatan presentasi antigen. Pengaruh akhir dari aktivitas IL10 ialah hambatan reaksi inflamasi non-spesifik dan spesifik yang diperantarai sel- $\mathrm{T}^{3}$.

Syzygium polyanthum dikenal juga sebagai daun salam ialah salah satu tanaman yang biasa digunakan untuk obat terutama di daerah Asia Tenggara, khususnya Indonesia ${ }^{4}$. Daun $S$. polyanthum mempunyai kandungan kimia minyak atsiri, flavonoid, dan $\operatorname{tanin}^{5}$. Kemampuan antiinflamasi daun $S$. polyanthum didapat dari kandungan flavonoid yang bekerja dengan cara menghambat siklooksigenase atau lipooksigenase ${ }^{4}$. Hasil penelitian sebelumnya menunjukkan, ekstrak daun S. polyanthum 10\% pada sediaan krim mempunyai efek antiinflamasi terhadap udema telapak kaki tikus yang terinduksi karagenin ${ }^{6}$.

Tujuan dari penelitian ini adalah menganalisa efek gel ekstrak daun salam ( $S$. polyanthum) terhadap jumlah ekpresi IL-10 pada proses penyembuhan ulkus traumatikus tikus galur wistar.

\section{METODE PENELITIAN}

Penelitian ini telah mendapat ijin dan persetujuan dari Komite Tim Etik Penelitian Fakultas Kedokteran Gigi Universitas Islam Sultan Agung dengan No. 133/B.1-KEPK/SAFKG/XI/2019.

Desain pemenilitan yang digunakan adalah penelitian analitik menggunakan rancangan true experimental laboratories post-test only. Perhitungan besar sampel berdasarkan rumus WHO, didapatkan jumlah sampel 5 ekor hewan per kelompok ${ }^{7}$. Dalam penelitian, terdapat kelompok kontrol negatif yang akan diberi gel Carbomer dan kelompok perlakuan yang diberi gel ekstrak daun $S$. polyanthum. Waktu pengambilan jaringan dibagi menjadi hari ke 3 dan 5 . Berdasarkan penjelasan diatas, maka total kelompok yang ada pada penelitian ini berjumlah 4 kelompok. Masingmasing kelompok berjumlah 5 ekor hewan coba. Dari perhitungan diatas, maka keseluruhan hewan coba di pada penelitian ini sebanyak 20 ekor tikus wistar jantan.

Pembuatan ekstrak diawali dengan memilih daun $S$. polyanthum segar. Daun yang dipilih merupakan daun dengan keadaan hijau segar, tidak layu, dan tidak kering. Daun $S$. polyanthum yang masih segar dikeringkan dengan menggunakan oven selama 2-3 hari. Setelah kering, daun $S$. polyanthum dihaluskan menggunakan blender dan ditimbang sebanyak 250 gram. Setelahnya, bubuk daun S. polyanthum dicampur dengan etanol 96\% (perbandingan 1:10) pada botol kaca yang dibalut dengan plastic hitam, lalu dimaserasi sepanjang 3 hari. Ampas disaring menggunakan kain flannel. Setelah itu disaring untuk kedua kalinya menggunakan vacuum filter. Selanjutnya filtrat diuapkan menggunakan rotary evaporator sampai menjadi ekstrak kental daun $S$. polyanthum. Ekstrak yang telah didapat kemudian dicampur dengan larutan carbomer 1,5\%, TEA 1 gram, metil paraben, dan gliserin. Semua bahan diaduk sampai homogen dan tidak ada partikel yang berbeda ${ }^{8}$.

Dua puluh ekor tikus diadaptasi selama 5 hari dan ditempatkan di kandang dengan isi 5 ekor tikus per kandang. Kandang diletakkan pada ruangan yang cukup cahaya dan udara. Suhu ruang diatur berkisar $20^{\circ}-28^{\circ}$ C. Siklus gelap-terang masing-masing selama 12 jam. Sebelum diberi perlakuan, setiap tikus dianestesi menggunakan ketamin yang diinjeksikan di bagian paha tikus. Ketamin dicampur akuades dengan perbandingan 7:3 dan setiap ekor diinjeksi $0.3 \mathrm{ml}$ campuran ketamin dan aquades. Mukosa labial diberi anestesi topikal dengan benzocaine $20 \%$ dan ditunggu selama 5 menit untuk memberi efek kebas ${ }^{9}$. 
Selanjutnya, mukosa tikus dibuat perlukaan menggunakan burnisher panas berdiameter $2 \mathrm{~mm}$ yang disentuhkan ke mukosa selama 1 detik $^{10}$. Semua hewan coba yang telah dibuat perlukaan dibagi menjadi 4 kelompok dan ditunggu sampai ulkus terbentuk selama 2-3 hari9.

Setelah ulkus terbentuk, dilakukan pengaplikasian gel ekstrak daun S. polyanthum dan gel carbomer sesuai kelompok sampai hari ke 3 dan 5. Selanjutnya, dilakukan dekapitasi sampel. Sampel dianestesi menggunakan inhalasi kloroform. Kemudian dilakukan pengambilan jaringan ulkus. Jaringan dimasukkan di kontainer berisi buffer formalin yang sudah diberi label ${ }^{9}$. Jaringan yang telah didapatkan dibuat preparat dan dilakukan pewarnaan secara imunohistokimia11,12.

Data yang diambil dari pewarnaan imunohistokimia adalah data kuantitatif yang dinilai menggunakan skor Hotspot, didasarkan pada banyaknya warna coklat yang dihasilkan dari pewarnaan IL-10 ${ }^{12}$. Pada area hotspot dilihat pembesaran 400x dengan mikroskop cahaya binokuler dan dibagi menjadi 5 lapang pandang. Ekspresi IL-10 dihitung pada masing-masing lapang pandang dan dibuat rata-rata ${ }^{13}$.

Data yang telah terkumpul dilakukan analisi data menggunakan SPSS. Digunakan uji normalitas Shapiro Wilk (jumlah sampel per kelompok <50). Digunakan uji homogenitas Levene Statistic. Bila data dinyatakan normal dan homogen (asymp sig>0.05), data dianalisis menggunakan uji independent $T$ - test. Bila data tidak normal dan tidak homogen (asymp sig<0.05), dilakukan analisis dengan uji Mann-Whitney.

\section{HASIL PENELITIAN}

Pembacaan preparat hasil penelitian (Gambar 1.) ditemukan sel makrofag dengan sitoplasma berwarna kecoklatan yang menunjukkan sel tersebut mengekspresikan IL-10. Terlihat pewarnaan coklat yang lebih banyak di kelompok perlakuan dibanding kelompok kontrol. Ini berarti ekspresi IL-10 pada kelompok perlakuan lebih banyak daripada kelompok kontrol.

Hasil perhitungan penelitian pengaruh gel ekstrak daun S. polyanthum terhadap ekspresi IL10 adalah sebagai berikut:

Dapat diketahui dari Tabel 1. bahwa ratarata IL-10 pada kelompok perlakuan lebih tinggi daripada kelompok kontrol. Kelompok kontrol hari ke-3 mempunyai rata-rata IL-10 terendah sedangkan kelompok perlakuan hari ke-5 mempunyai jumlah rata-rata IL-10 tertinggi.

Tabel 1. Jumlah Rerata Ekspresi IL-10

\begin{tabular}{ccccc}
\hline $\begin{array}{c}\text { Kelompo } \\
\mathbf{k}\end{array}$ & $\begin{array}{c}\text { Kontr } \\
\text { ol hari } \\
\text { ke-3 } \\
\text { (C1) }\end{array}$ & $\begin{array}{c}\text { Perlakua } \\
\text { n hari ke- } \\
\mathbf{3}(\mathbf{P 1})\end{array}$ & $\begin{array}{c}\text { Kontr } \\
\text { ol hari } \\
\text { ke-5 } \\
\text { (C2) }\end{array}$ & $\begin{array}{c}\text { Perla } \\
\text { kuan } \\
\text { hari } \\
\text { ke-5 } \\
\text { (P2) }\end{array}$ \\
\hline $\begin{array}{c}\text { Jumlah } \\
\text { Sampel }\end{array}$ & 5 & 5 & 5 & 5 \\
\hline Rata-Rata & 14,28 & 20,96 & 21,18 & 31,8 \\
\hline $\begin{array}{c}\text { Standar } \\
\text { Deviasi }\end{array}$ & 0,26 & 1,09 & 0,94 & 0,64 \\
\hline
\end{tabular}

Analisis statistik dilakukan dalam mengetahui pengaruh pemberian ekstrak daun $S$. polyanthum terhadap ekspresi IL-10 diawali dengan melakukan uji normalitas dan homogenitas berikut:

Tabel 2. Uji Normalitas Sapphiro-Wilk

\begin{tabular}{ccc}
\hline Kelompok & Sig. $\mathbf{P}$ & Keterangan \\
\hline $\begin{array}{c}\text { Kontrol hari } \\
\text { ke-3 }\end{array}$ & 0,201 & $\begin{array}{c}\text { Data terdistribusi } \\
\text { normal }\end{array}$ \\
\hline $\begin{array}{c}\text { Perlakuan hari } \\
\text { ke-3 }\end{array}$ & 0,979 & $\begin{array}{c}\text { Data terdistribusi } \\
\text { normal }\end{array}$ \\
\hline $\begin{array}{c}\text { Kontrol hari } \\
\text { ke-5 }\end{array}$ & 0,190 & $\begin{array}{c}\text { Data terdistribusi } \\
\text { normal }\end{array}$ \\
\hline $\begin{array}{c}\text { Perlakuan hari } \\
\text { ke-5 }\end{array}$ & 0,111 & $\begin{array}{c}\text { Data terdistribusi } \\
\text { normal }\end{array}$ \\
\hline
\end{tabular}

Uji normalitas yang telah dilakukan menunjukkan semua kelompok terdistribusi normal karena $P>0,05$. 
Tabel 3. Uji Homogenitas

\begin{tabular}{ccc}
\hline $\begin{array}{c}\text { Kenaikan } \\
\text { Skor }\end{array}$ & Sig. P & Keterangan \\
\hline $\begin{array}{c}\text { Based on } \\
\text { mean }\end{array}$ & 0,346 & Data homogen \\
\hline
\end{tabular}

Didapatkan sig. (P) 0,346 sehingga menunjukkan nilai $p>0.05$, maka sebaran semua data kelompok dinyatakan homogen. Berdasarkan hasil uji normalitas serta homogenitas, penelitian dilanjutkan dengan uji Independent T-Test.

Data Tabel 4. Menunjukkan terdapat perbedaan yang signifikan pada ekspresi IL-10 antara kelompok kontrol dan perlakuan di hari ke-3 dan 5. Data pada Tabel 5. memperlihatkan bahwa terdapat perbedaan signifikan di kelompok perlakuan hari ke 3 dan 5 .
Tabel 4. Hasil Uji Independent T-Test per kelompok hari

\begin{tabular}{ccccc}
\hline $\begin{array}{c}\text { Hari } \\
\text { ke- }\end{array}$ & Kelompok & $\mathbf{P}$ & Sig. & Hasil \\
\hline 3 & $\begin{array}{c}\text { Kontrol } \\
(\mathrm{C} 1)\end{array}$ & 0,000 & $\mathrm{P}<0,05$ & Signifikan \\
\cline { 2 - 3 } & $\begin{array}{c}\text { Perlakuan } \\
(\mathrm{P} 1)\end{array}$ & & & \\
\hline 5 & $\begin{array}{c}\text { Kontrol } \\
(\mathrm{C} 2)\end{array}$ & 0,000 & $\mathrm{P}<0,05$ & Signifikan \\
& $\begin{array}{c}\text { Perlakuan } \\
(\mathrm{P} 2)\end{array}$ & & & \\
& & & \\
\hline
\end{tabular}

Tabel 5. Hasil Uji Independent T-Test Kelompok Perlakuan

\begin{tabular}{ccccc}
\hline Kelompok & $\begin{array}{c}\text { Hari } \\
\text { ke- }\end{array}$ & $\mathbf{P}$ & Sig. & Hasil \\
\hline Perlakuan & $\begin{array}{c}3 \\
(\mathrm{P} 1)\end{array}$ & 0,000 & $\mathrm{P}<0,05$ & Signifikan \\
& & & \\
& & & \\
& $(\mathrm{P} 2)$ & & & \\
\hline
\end{tabular}

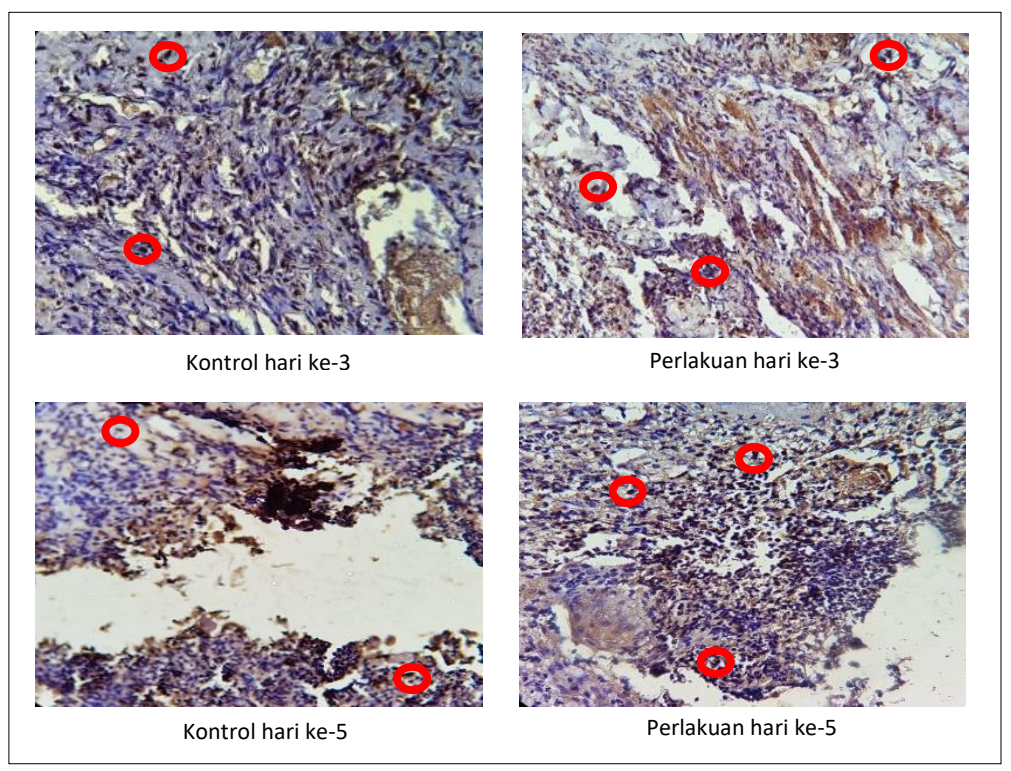

Gambar 1. Gambaran histologi perbandingan antara kelompok kontrol dan kelompok perlakuan gel ekstrak daun S. polyanthum dengan pembesaran $400 x$ 


\section{DISKUSI}

Hasil dari penelitian yang telah dilakukan menunjukkan bahwa terdapat peningkatan ekspresi IL-10 yang signifikan pada kelompok yang diberi perlakuan dengan gel ekstrak daun S. polyanthum $10 \%$ dibandingkan kelompok kontrol. Hasil yang didapatkan dari penelitian ini sesuai dengan penelitian yang sudah dilakukan oleh Utama tahun 2014 yang menunjukkan ekstrak daun S. polyanthum 10\% pada sediaan cream mempunyai efek antiinflamasi terhadap udema telapak kaki tikus yang terinduksi karagenin 6 .

Penelitian ini menggunakan gel ekstrak daun $S$. polyanthum sebagai perlakuan. Daun $S$. polyanthum dipilih karena mempunyai kandungan kimia minyak atsiri, flavonoid, dan $\operatorname{tanin}^{5}$. Tanin berfungsi sebagai antibakteri sehingga dalam proses penyembuhan luka gel ekstrak daun $S$. polyanthum mampu mengurangi pertumbuhan bakteri penyebab inflamasi ${ }^{14}$.

Essential oil sebagai antiseptik memiliki fungsi untuk mengurangi penyebaran bakteri dan jamur pada bagian yang terluka ${ }^{15}$. Flavonoid sebagai anti-inflamasi memiliki fungsi menurunkan sekresi sitokin pro-inflamasi dan meningkatkan sitokin anti-inflamasi ${ }^{4}$.

Hasil penelitian memperlihatkan bahwa gel ekstrak daun S. polyanthum 10\% mampu meningkatkan jumlah ekspresi IL-10 pada penyembuhan ulkus traumatikus mukosa mulut tikus wistar. Hal ini dilihat dari rata-rata jumlah ekspresi IL-10 pada kelompok perlakuan hari ke 3 dan hari 5 lebih tinggi dibandingkan dengan jumlah rata-rata ekspresi IL-10 pada kelompok kontrol. Hasil uji statistik juga menunjukkan bahwa terdapat perbedaan yang signifikan pada ekspresi IL-10 antara kelompok kontrol dan perlakuan baik pada hari ke 3 maupun hari ke 5 . Peningkatan jumlah ekspresi IL-10 dikarenakan daun S. polyanthum mengandung flavonoid yang bersifat anti-inflamasi ${ }^{16}$.

Mekanisme flavonoid sebagai antiinflamasi mirip dengan NSAID, yaitu dengan menghambat siklooksigenase atau lipooksigenase sehingga menghambat sintesis prostaglandin dan stimulasi hidroksilasi prolin ${ }^{17}$. Flavonoid juga menghambat aktivasi jalur signaling intaseluler NFK $\beta$, yang akan menyebabkan turunnya sekresi sitokin dan kemokin pro-inflamasi ${ }^{16}$. Selain itu, flavonoid juga menyebabkan peningkatan jumlah makrofag $\mathrm{M}^{18}$. Makrofag $\mathrm{M} 2$ akan mensekresikan sitokin anti-inflamasi, diantaranya IL-4, 10, serta 13. Sehingga, dengan banyaknya makrofag M2 produksi sitokin antiinflamasi, salah satunya IL-10, akan semakin banyak $^{19}$.

IL-10 adalah sitokin antiinflamasi yang diproduksi oleh makrofag teraktivasi, sel $B$, dan sel-T. IL-10 berfungsi utama sebagai penghambat produksi sitokin pro-inflamasi, seperti TNF, IL-1 $\beta$, IL-6, IL-8, IL-12, dan GM$\mathrm{CSF}^{20}$. Selain itu, IL-10 juga menghambat fungsi makrofag dan sel dendritik dalam membantu aktivasi sel-T, sehingga bersifat imunosupresi. IL-10 akan menekan ekspresi MHC-II pada permukaan makrofag dan mengurangi ekspresi ko-stimulator ${ }^{3}$. IL-10 juga menurunkan aktivitas mikrobisida makrofag dan mengurangi sensitivitas makrofag untuk merespon IFN- $\gamma$ sehingga terjadi hambatan presentasi antigen 20. Dampak akhir dari aktivitas IL-10 adalah hambatan reaksi inflamasi non-spesifik maupun spesifik yang diperantarai sel-T 3 .

Gel ekstrak daun S. polyanthum dapat digunakan sebagai alternatif untuk menyembuhkan ulkus traumatikus dengan cara meningkatkan sekresi IL-10 dan mempercepat fase inflamasi. Hal ini karena kandungan 
flavonoid pada daun S. polyanthum dapat meningkatkan produksi IL-10 yang berperan sebagai anti-inflamasi pada penyembuhan ulkus. Ini sesuai dengan pernyataan López et al. ${ }^{16}$ bahwa flavonoid dapat menghambat aktivasi jalur intraseluler NFK $\beta$ dan meningkatkan jumlah makrofag M2, sehingga menyebabkan produksi sitokin anti-inflamasi menjadi lebih tinggi ${ }^{16}$. Tingginya sitokin anti-inflamasi akan menyebabkan penyembuhan luka menjadi lebih cepat $^{21}$.

\section{KESIMPULAN}

Dapat disimpulkan bahwa gel ekstrak daun salam (Syzygium polyanthum) 10\% memiliki efek yang signifikan dalam meningkatkan ekspresi IL-10 pada penyembuhan ulkus traumatikus mukosa mulut tikus wistar.

\section{UCAPAN TERIMAKASIH}

Ucapan terima kasih pada berbagai pihak yang mendukung penelitian ini, khususnya kepada institusi peneliti yaitu Fakultas Kedokteran Gigi Universitas Islam Sultan Agung.

\section{DAFTAR PUSTAKA}

1. Sunarjo L, Hendari $R$, Rimbyastuti $H$. Manfaat Xanthone Terhadap Kesembuhan Ulkus Rongga Mulut Dilihat dari Jumlah Sel PMN dan Fibroblast. ODONTO Dent J. 2015;2(2):14-21.

2. Langlais RP, Miller CS, Gehrig JS. Color Atlas of Common Oral Diseases. 5th Edition. Philadelphia: Lippincott Williams \& Wilkins; 2016.

3. Kresno SB. IMUNOLOGI: Diagnosis dan Prosedur Laboratorium. Edisi 5. Jakarta: Badan Penerbit Fakultas Kedokteran Universitas Indonesia; 2013. 114 p.

4. Silalahi M. Syzygium polyanthum (Wight) Walp. (Botani, Metabolit Sekunder dan Pemanfaatan). J Din Pendidik. 2017;10(1):1-16.

5. Harismah K, Chusniatun. Pemanfaatan daun salam (Eugenia polyantha) Sebagai
Obat Herbal dan Rempah Penyedap Makanan. War LPM. 2016;19(2):110-8.

6. Utama TIW. Formulasi Sediaan Krim Ekstrak Etanolik Daun Salam (Eugenia polyantha Wight.) Dengan Pengujian Aktivitasnya Sebagai Anti Inflamasi Topikal Pada Tikus. Universitas Sanata Dharma; 2014. 53 p.

7. Sastroasmoro S, Ismael S. Dasar-dasar Metodologi Penelitian Klinis. 4th ed. Jakarta: Sagung Seto; 2011. 86 p.

8. Megawati, Yacobus AR, Akhir LO. Formulasi Dan Uji Stabilitas Fisik Sediaan Gel Ekstrak Kulit Buah Rambutan (Nephelium lappaceum L.) Sebagai Obat Sariawan Menggunakan Variasi Konsentrasi Basis Carbopol. [JFS] J Farm Sandi Karsa. 2019;5(1):5-10.

9. Mujayanto R, Harijanti K, Hernawan I. Topical application of $1 \% \mathrm{ZnSO} 4$ on oral ulcers increases the number of macrophages in normal or diabetic conditions of wistar rats. Dent J (Maj Ked Gigi). 2016;49(3):133-6.

10. Kartikandari RM. Analisa Gel Ekstrak Daun Kelor (Moringa oleifera) Terhadap Jumlah Makrofag Pada Penyembuhan Ulkus Traumatikus Mukosa Mulut (In Vivo). Universitas Islam Sultan Agung; 2017. 30 p.

11. Astari ED. Pengaruh Sari Bonggol Nanas (Ananas comosus (L.) Merr.) terhadap Jumlah Fibroblas pada Proses Penyembuhan Ulkus Traumatikus pada Tikus Galur Wistar. Universitas Islam Sultan Agung; 2016. 47 p.

12. Setiorini $Y$, Wresdiyati T. Deteksi Secara Imunohistokimia Imunoglobulin A (IgA) pada Usus Halus Tikus yang Diberi Bakteri Asam Laktat (BAL) dan Enteropatogenik Escherichia coli (EPEC). Institut Pertanian Bogor; 2012. 64 p.

13. Hartayati MD. Hubungan Positif Ekspresi Cyclooxygenase-2 dengan Microvessel Density pada Undifferentiated Carcinomanasophar YNX di RSUP Sanglah Denpasar. Universitas Udayana Denpasar; 2015. 38 p.

14. Agustina R, Indrawati DT, Masruhin MA. Aktivitas Ekstrak Daun Salam (Eugenia polyantha) Sebagai Antiinflamasi pada Tikus Putih (Rattus norvegicus). J Trop Pharm Chem. 2015;3(2):120-3.

15. Rizky MI, Hariandja M. Review : Aktivitas Farmakologis, Senyawa Aktif, dan Mekanisme Kerja Daun Salam (Syzygium polyanthum). In: Prosiding Seminar Nasional \& Workshop "Perkembangan Terkini Sains Farmasi \& Klinik 5." Padang: Prodi Farmasi FMIPA, 
Universitas Lambung Mangkurat, Banjarbaru; 2015. p. 239-44.

16. López NL, Grijalva EPG, Perez DLA, Heredia JB. Flavonoids as cytokine modulators: A possible therapy for inflammation-related diseases. Int $\mathrm{J} \mathrm{Mol}$ Sci. 2016;17(6):921.

17. Ramadhani N, Sumiwi SA. Aktivitas Antiinflamasi Berbagai Tanaman Diduga Berasal Dari Flavonoid. Farmaka. 2015;14(2):111-23.

18. Saqib U, Sarkar S, Suk K, Mohammad O, Baig MS, Savai R. Phytochemicals as modulators of M1-M2 macrophages in inflammation.

Oncotarget. 2018:9(25):17937-50.

19. Landén NX, Li D, Ståhle M. Transition from Inflammation to Proliferation: $A$ Critical Step During Wound Healing. Cell Mol Life Sci. 2016;73(20):3861-3885.

20. Duque GA, Descoteaux A. Macrophage Cytokines: Involvement in Immunity and Infectious Diseases. Front Immunol. 2014;5(491):1-12.

21. Larouche J, Sheoran S, Maruyama K, Martino MM. Immune regulation of skin wound healing: Mechanisms and novel therapeutic targets. Adv Wound Care. 2018;7(7):209-31. 